\title{
PADLETas MEDIA to IMPROVE WRITING MASTERY of ENGLISH DEPARTMENT STUDENTS of UNISKA 2015-2016
}

\author{
Pritantina Yuni Lestari, M.Pd \\ English Education Department \\ FKIP, UNISKA \\ Kediri, Indonesia \\ pritantinayl@gmail.com
}

\begin{abstract}
- multimedia has been spread out and used by many students in their lives, but it rarely uses multimedia as one of medias that used in teaching learning process. The objective of this study is to know whether the use of padlet as the media that can improve the students' mastery in descriptive writing, especially the students in the third semester of english departement of uniska. The research's design used was classroom action research, consisted of two cycles. Each cycles consisted of three opportunities for students to have interaction using padlet. The cycles consisted of planning, implementing, observing and reflecting. The instruments used in this research were observation check list and writing test using padlet. Padlet was introduced from the first time of learning teaching process in the class and the following interactions were using padlet without having direct interaction in the classroom. The first cycle was not successful, because the students got difficulty in managing time in accessing padlet and some errors in their grammatical used. Then in the second cycle, the result showed that 18 from 20 students passed the minimum score and all students did all assignments using padlet. From the result, it can be concluded that the implementation of padlet as the media can improve students' writing mastery.

Keywords - padlet, writing mastery, descriptive writing
\end{abstract}

\section{INTRODUCTION}

English as one of the international languages in the world should be mastered by people from many countries in the world to communicate each other. They may know and understand what they speak communicatively because of English, and by the reason above, English becomes the first foreign language that is taught in Indonesia started from elementary school up to university. Writing is one of the four basic language skills: listening, writing, reading and speaking. 1 is the process of giving the English lesson, from the teachers to the students based on the materials, in order that the students are able to absorb it and they will be able to communicate by written text.

Writing is a way of gaining control over your ideas and getting them down on paper. There is nothing mysterious

\author{
Erwin Hari Kurniawan, M.Pd \\ English Education Department \\ FKIP, UNISKA \\ Kediri, Indonesia
}

about this process, and you can learn to write effectively and feel confident about your writing, if you are willing to put in time and efforts. Many people find it necessary to write at one particular place, or with a certain color of ink, or a special type of keyboards. Having these things may help you write, but more important than these is developing the ability to concentrate. Sometimes it will be necessary to tune everyone and everything out in order to reflect inwardly and recreate incidents that you have read or heard about, experienced, or observed with total concentration. You can "replay" these incidents and share them with your readers, for instance, if you want to remember that first day of school long ago when you were six years of age all you have to do is close your eyes until a mental picture enters your mind. That room, that teacher, that moment of fear, happiness, or excitement can be a video played in your mind. Reference [11] And from your "mind's video" you can write your thoughts on paper to share with your readers.

Reference [6] In writing, people learn better from words and pictures than from words alone. Multimedia instruction consists of words and pictures rather than words alone. The case for multimedia learning rests on the premise that learners can better understand an explanation when it is presented in words and pictures than when it is presented in words alone.

Relating to writing, descriptive writing appeals to the senses, so it tells how something looks, feels, smells, tastes, and/or sounds. A good description is a word picture; the reader can imagine the object, place, or the person in his or her mind. Reference [7] A description usually follows a pattern of organization that we call spatial order. Spatial order is the arrangement of things in space. As you read the models of paragraphs, notice how the description moves from the bottom of the stairway to the top. Also notice how the description of the woman moves from far away to near. In descriptive text, the generic structures are identification and description. Identification describes the identification of object mentioned. Then, descriptive text describes the characteristics and the description of the object. Language feature using attributive and identifying process, adjective and classifiers in nominal group, simple present tense in term of 
generic structures refers to the series of requirement of elements in constructing descriptive text.

In UNISKA, especially the students of the third semester had problem in writing, especially in structures and developing ideas to be a good composition. It was known when they submitted their papers of the descriptive text to the writing lecturer. The dialogue of the writing lecturer with the researcher tried to think about the alternative solution of the problem above. Based on Jacobs in ESL Composition Profile stated inReference [9], there are five aspects in scoring writing. They are content, organization, vocabulary, structure/ language use, and mechanic. From those it can be inferred that students' score in writing descriptive is lower than the minimum score criteria.

Reference [10] stated that the $21^{\text {st }}$ century world is characterized by the emergence of the second wave of globalization, if the first was triggered by technology, the second was by ICT. Now ICT has made distance face to face communication possible. ICT has led teachers to take new perspective in their teachings. ICT makes teacher aware of the using of multimedia in teaching learning process. Before it, multimedia has been a part of our language since 1950s. It has been used to refer many great aspects of communication and technology and therefore is difficult to be precisely defined. According to reference [8], multimedia refers to any synchronized stream Medias. One example is that moving images synchronized with sound. In the other side, reference [3] stated that multimedia relates to any combination of two or more media formats that are integrated to form an informational program.

Concerning to the multimedia used in teaching, Padlet (http://Padlet.com/), formerly a Wall Wisher, is a webspace where the admin can add files, links, videos, and more. By using this, tutors can create various walls to add their favorite contents. Tutors/teachers may develop the wall to collect and share a few of their favorite technology resources. People can also collaborate to continue adding the same wall spaces. By using this, it can create a live discussion among the tutors and the students also co-tutors.

Further Reference [1] gave comment related to the implementation of ICT, that when using technology as the meaning of encouraging the whole-class participation in classroom activities, there are benefits and risks to be considered. First and foremost among the benefits, is the idea of technology as the great equalizer, particularly, when the participants havetheir options to be anonymous, for example if the students are not confident in their ideas or not sure if they have the right answer, any chances of failure is minimized when no one knows what answer they type. This realization can allow more freedom and experimentation in the learning process. In addition, students are drawn to the novelty of the technology and seem to want to participate just to have the opportunity to use it. A final benefit of real-time participatory technology is that it can give the teachers more complete pictures of learning from all students, rather than from the handful of the most vocal or the most confident ones. The teacher can use thoseinformatios to inform the lesson's developments, create more targeted and authenticated interactions betweenthe teachers and the students.

Reference [1] also stated that there are some problems. The first, technology is fickle and unpredictable, as any librarian instructions already attested to. Internet access comes and goes, and sites go down for maintenance without any warnings. When the teachers use technology in the classroom, they are at its mercy, and that fact alone may be enough to repel people from using it. With so many unknowns already existed in the classroom, it may seemlike an act of sheer insanity to knowingly introduce another one. Another risk is that real-time means real-time. Students may use the ability to instantaneously see other students' responses as an opportunity to use the technology as a personal stage for silliness. A final risk is that some may perceive the uses of new technology in the classroom as an educational "smoke and mirrors" and also may question its value for teaching. In an effort to be an intentional, purposeful teacher, he considers that it's important to explain to classes the educational significance associated with the activities, so he also makes it a point to explain the rationale behind the classroom uses of this technology with students.

Based on the explanation above, the researcher wanted to apply Padlet as the media used to improve students' writing achievements. Before applying it at first, the researcher did a study to operate and understand the typical of Padlet and compare it with other on line medias, such as WhatsApp, email, moodle, etc. After knowing the characteristics, some advantages and disadvantages of using Padlet and how to operate it in teaching learning, the researcher conducted a research using Padlet as the media to improve the writing achievements of the third semester's students of English Department of UNISKA Kediri. The formulation of the research was: how Padlet is able to improve the writing achievements of the third semester's students of English Department of UNISKA Kediri.

The type of writing used in this study was limited in the mastering of descriptive texts studied by the first semester of English Department UNISKA Kediri in the 2014-2015 academic years. The stages of writing process that were applied were pre-writing, continued by drafting. After that the students should do a proofreading and an editing before they publish their writings.

The findings of this study are expected to have theoretical and practical contributions. First, from the theoretical view, it is expected to support the theory of applying Padlet in writing teaching. Then, viewed from the practical, this research gives meaningful contributions to the lecturers, students and future researcher. The students can apply Padlet as the media used in learning writing. Then, for the lecturers this media is useful to help them in teaching learning practice. The role of the future research of Padlet, this research will be the consideration in applying Padlet for other researchs. 


\section{METHOD}

The design of this study was Classroom Action Research which had four steps in each cycles, which consistedof: planning, implementing, observing and reflecting. This cycle was adapted from the model proposed by reference [4], which focused on a particular group of students in the third semester of "A class" of English Department of UNISKA Kediri in a certain classroom. Thus, the classroom action research in the study was implemented for the purpose of improving writing achievements of the students in descriptive text by using Padlet as the media used. The implementation of it was expected to improve the students' writing achievements.

The setting of the research was done in the third semester of 2015-2016 academic years. The class had 17 students who had low in mastering the descriptive text. This study was associated with the general idea of improving the students' writing achievements in descriptive text. The general idea focused on improving the students' writing achievements by using Padlet as the media used in discussing, doing assignment, and commenting their duties submitted among the students and the lecturers. Then, the preliminary study phase was conducted. After that the researcher implemented the research.

In preliminary study, the researcher did some activities as follows. The first step, the researcher did preobservation. This activity was done to know the pre-condition before the observation, especially the results of the students' writing achievements. It was taken from the paper's scores submitted to the third writing lecture. In this time, the researcher tried to find out the problems that made students feel difficult in writing. It could be taken from the interview and the direct observation. Having done the observation, the researcher identified the problems that happened in their writings. The problemsappeared were: The researcher stated that the students were weak in writing. It can be identified from their grammatical errors, developing ideas to the composition and coherences and unities in their papers. The achievements of the students' writings can be identified as below:

\begin{tabular}{|c|c|}
\hline Total & 1124 \\
\hline Mean & 66,11 \\
\hline Min & 55 \\
\hline Max & 80 \\
\hline Median & 65 \\
\hline N & 17 \\
\hline
\end{tabular}

Having been identified, it can be concluded that the students' writing achievements were still weak and under qualified, because there were 11 students from 17 students got score below 70. If it is clarified and described, it can be elaborated as below: the students got difficulty in grammaticals, developing ideas, coherences and unities in their writings. Besides, those most of students who got difficulty did not have bravery to ask the lecturer if they did not understand the lesson given.

Based on those two facts, the researcher decided that the students' organizing ideas' skill needed to be improved. In this research, the researcher and his collaborator prepared instructional materials used in the implementation of every teaching learning processes. Firstly, the researcher and the collaborator prepared the materials which supported the teaching learning process, especially related to the Team Pair Share. The researcher and the collaborator prepared the books supported the analytical exposition texts and the questions given. The researcher and the collaborator tried to make aninteresting media to support the writing teaching using Team Pair Share.

The students were considered successful, if they meet the criterias of success as follows: (1) More 75\% students are actively involved doing the teaching and learning process using Padlet, (2) The students' writing comprehension'simproveness could be seen from the results of each cycles, (3) All of the students could achieve the passing grade of the writing'sachievementt, that was 70

\section{FINDINGS}

\section{Findings from Cycle I}

\section{The Students' Achievement}

Concerning to the research on the students' writings in Cycle I, it can be stated the students' achievements in writing descriptive text in Cycle I were not adequate yet. It was found that the average score of this cycle was 66.11.It was greater than the preliminary study that was 65.00 . Then, if we compared this condition with the criterias of success viewed from score, it could be stated that the students' achievements in writing did not achieve the criteria of success.

This condition happened because of two factors. First, some students got difficulty in differing the using of "be" and "verb' as the predicate in their sentences. The second, the students still got difficulty to differ whether it isa fragment or a sentence. Some of them got difficulty in running on the sentences. It could be seen from their writings starting from the pre writing until the publishing of their writings in Padlet.

\section{The Students' Involvement}

Based on the result of the analysis of the data gained from the observation checklist in Cycle I, it showed that the students' involvement in the writing activities were categorized as fair. There were 2 of 17 students did not follow the first meeting, so the procedures of the learning teaching's process using Padlet could not bemaximizely used by the students. Some of the students directly wrote without passing the steps of writing.

The following problems were, some students were late in submitting their tasks on time, although there was a message sent using short message service to all students and message posted in the Padlet about what they should do and the deadline of the task that they should submit. In this cycle there were only 15 students participated in this research, where 2 of 14 students were late in submitting their final tasks which were used as the treatment score. 


\section{Revision on the Strategy}

Based on two conditions above, the criterias of success had not been achieved yet, so the following cyclesshould be done. From the scoring criterias it was known that the problems of the students in grammatical errors, fragmentings and running on the sentences should have been reduced in the following cycles. Giving explanation related to the grammatical errors and giving exercises would be the first consideration. At the first day students should read the example and discuss it with their friends. The following day the students would do some exercises related to the grammatical errors. The third day the students would be given some explanations and exercises related to the fragments and how to overcome it. The third day the students should observe the run on sentence and how to overcome it. Then on the following days, the students were given some artists' pictures to be created into pre writing, continued to be created in to drafting and pasting it in to Padlet to be read by their friends to get some inputs and revisions. Then they should edit and publish their writing's revisions to the Padlet to take their scores.

Related to the students' motivations and participations, the students were gathered to get the explanations and how to have interaction in teaching learning process using Padlet. All students were given motivations of the importances of their participations in order they could pass the cycles by getting the satisfactory score result. The researcher asked their mobile number to be contacted if they did not submit their participations by the deadline. Here, the researcher also emphasized the process of writing starts from the pre-writing by using pictures as the brain storming, drafting their ideas, asking their friends to read and comment, and editing their writings before they post it. Those activities were done before implementing the teaching learning using Padlet.

\section{Findings from Cycle II}

\section{The Students' Achievement}

Based on the analysis of the students' compositions in Cycle II, the findings showed that the students' average writing achievements increased from 71 in the first cycle to be 76 in the second treatment. 16 students got score above 70 and only one students got score 68 . The maximum score was 85 . The mean score was 75 .

Even though the students' achievements in writing improved, it was still found the certain types of mistakes made by the students in the students' writings. Two students got problem in running on thesentences, 3 students got problem in fragmenting and one students in verbalizing the picture into their writings. Overall the students could achieve their writings, especially in descriptive text. Based on the condition of the students' achivements, the process of classroom action research could be stopped.

\section{The Students' Involvement}

Here, the researcher observed students' activities during the implementation of Padlet as the media in learning teaching process using checklist, from the checklist it is known that all the processes were using the Padlet. The weakness about the participation of the students in the first cycle could be overcame by doing the second cycle. And the students could write and develop their ideas using the steps of writing a text, passing pre-writing, outlining, proofreading, editing and publishing.

In this cycle all students participated teaching learning process using Padlet as schedule given in the first meeting of this cycle. The explanation and motivation in the first meeting given by the lecturer gave positive effect toward their participation. Besides that the given of message using WhatsApp group and short message service every morning to remain students toward their task that they should do could maximize their participation.

\section{DISCUSSIONS}

From the research above, it provided more informations and datas that the implementation of Padlet as the media in learning teaching process of writing a descriptive text can improve students' writing achievements, which was indicated by the result of each cycles. From the observation checklist, it could be known that students' activeness improved in the second cycle compared from the first cycle. The implementation of sending messages and giving interesting topics could drag the motivation to participate and study using Padlet. The used ofPadlet as the media form in studying English could make the students and lecturers studied together without having time and place border. It is in line with Reference [5]statement about the advantages of Padlet as the media in learning teaching process and reference[10] statement that the implementation of ICT in learning teaching process can change the new perspective in teacher's teaching.

Then related to the result of the cycles, it could be seen from the graph below that in the preliminary study, it can be concluded that the students' writing achievements were still weak and under qualified, because there were 11 students from 17 students got score under 70 . Then in the first, were 3 students got score under 70 and two students did not submit their tasks on time so they did not get the score. In the last treatment, the criteria had been achieved well, so the researcher could stop the cycle. Students' participation reached $100 \%$, it could be seen from all students' participation in discussion, submitting the second until the third task on time. The errors that were made during the task were falling down.

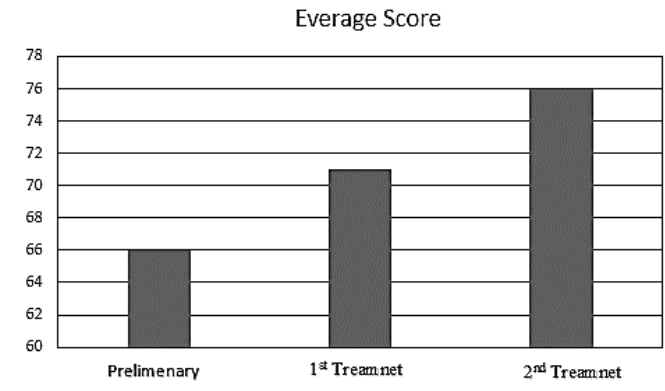


Figure1. Students'Achievement Scores

Related to the students' participation, in the preliminary research, all students participated $100 \%$. Then in the first treatment only $88,23 \%$ (15 of 17 students) participated actively in the learning teaching process using Padlet as the media in writing teaching. Then after giving motivation, explanations and guidancse using social media and SMS, the students' involvement could be $100 \%$ in the last cycle.

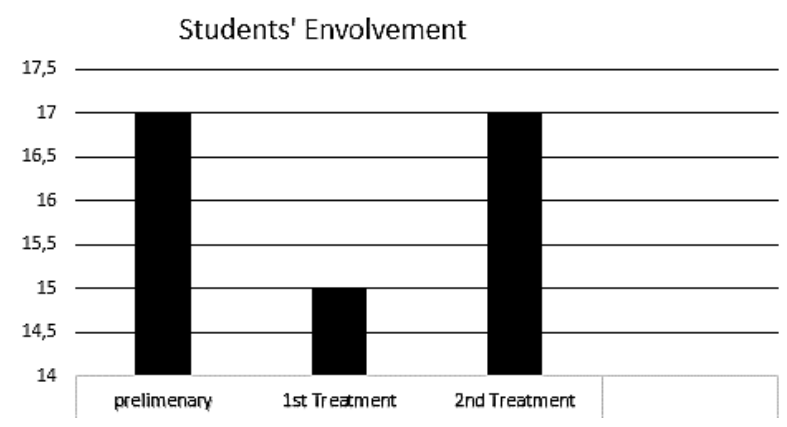

Figure 2. Students' Involvement

Based on the condition above it could be stated that by giving attention and intense communication, teaching descriptive text using Padlet as media could improve students' achievement.

\section{CONCLUSION AND RECOMMENDATION}

Based on the implementation of Padlet in teaching writing descriptive text, the researcher concluded that Padlet can improve students' writing achievements. The problem in the first cycle happened because on the first meeting not all students could come and understand the process of learning using Padlet. The chosen of interesting topics and given awareness to participate and finish the task well and explained the gain of the process of studying, shared, uploaded and commented or discussed using Padlet in the beginning of the second cycle and sent message to remain them to finish the tasks on time also gave positive impacts for the students to achieve their participations, be active and finish their tasks well.

From those, it could be concluded and suggested that Padlet can be considerated as the media in learning teaching process applied in other skills, such as designing interesting layout, well introduction and interesting topic to be discussed and examined.

Related to the results, some suggestions are proposed to the lecturers, students and future researchers. The lecturers of writing are recommended to apply Padlet by having enough preparation in developing materials presented in the class and posted in the Padlet, to have clear explanation before asking the students to do the activities related to the learning teaching process and to give feedback to the students' works and to control students' participation by using short message service to the students who do not understand or do not do the tasks.
To the students, it is suggested that they follow all the processesof the learning teaching process both in the classroom and in the virtual using Padlet. The following researchers are expected to do some innovations in other textss of writing process or in other subject which may be appropriate. The last, the researcher gives gratitude to those who contributed in this study, and who concern with its recommendations.

\section{REFERENCES}

[1] Fuchs, B. Online (2014). The Writing is on the wall: Using Padlet for Whole-Class Engagement. (Accessed from University of Kentucky Libraries. (online)URL: https://docs.google.com/presentation/d/102ajRlZ0bDby 07MhC79NdxyTSMLHXuTbZNJ4fpsYHw/edit?pli=1) ((Accessed on 21 August 2015)

[2] Green, TD and Brown, A. (2002). Multimedia Projects in the Classroom. California: Corwin Press

[3] Heinich, R., Molenda, M., Russel, J., Smaldino, S. (1999) Instructional media and Technologies for Learning ( $6^{\text {th }} e d$.). NJ: Merrill/Prentice Hall.

[4] Kemmis, S \&McTaggart, R. (1992) The Action Research Planner ( $3^{\text {rd }}$ edition). Victoria: Deakin University Press.

[5] Klein, E. Online (2013). Using Padlet in the Classroom to Collaborate \& Create Interactive sticky notes! (online)URL: http://www.kleinspiration.com/p/ (Accesed on 21 August 2015)

[6] Mayer, RE. (2009). Multimedia Learning. New York: Cambridge University Press

[7] Oshima, A., Houge, A. (2007) Introduction to Academic Writing ( $3^{\text {rd }} E d$.) New York: Pearson Education, Inc.

[8] Rada, R. (1995) Interactive Media. New York: Springer-Verlag.

[9] Safitri, M. (2008). The Effectiveness of Describing Picture Technique to Improve Writing Ability of The First Year Students of MTs Negeri Kediri 2. Unpublished Thesis. Kediri: FakultasKeguruandanIlmuPendidikanUniversitas Islam Kadiri.

[10] Suherdi, D. (2012). Towards the $21^{\text {st }}$ Century English Teacher Education. Bandung: Celtic Press

[11] Wingersky, J., Boerner, J., Balogh, DH. (1992). Writing Paragraphs and Essay: Integrating Reading, Writing, and Grammar Skills. California: Wadsworth Publishing Co Inc. 